\title{
Effect Of 20\% Bleaching Agent on Surface Roughness of Restorative Materials-An In Vitro Study.
}

\author{
1 Dr. Aditya vardhan Patidar, 2 Dr. Manoj Chandak, ${ }_{3}$ Dr. Bernice Thomas, \\ ${ }_{4}$ Dr. kaustubh Khatod, ${ }_{5}$ Dr. Nikita Patidar \\ ${ }_{1}$ M.D.S, PG student Department of Conservative and Endodontics, Sharad Pawar Dental College, Wardha, \\ Maharastra,India. \\ ${ }_{2}$ M.D.S, Professor and H.O.D, Department of Conservative and Endodontics, Sharad Pawar Dental College, \\ Wardha, Maharastra,India. \\ ${ }_{3}$ M.D.S, PG student Department of Conservative and Endodontics, Sharad Pawar Dental College, Wardha, \\ Maharastra,India. \\ ${ }_{4}$ M.D.S, PG student Department of Conservative and Endodontics, Sharad Pawar Dental College, Wardha, \\ Maharastra,India. \\ ${ }_{5}$ M.D.S, PG student Department of Prosthodontics, Sharad Pawar Dental College, Wardha, Maharastra,India.
}

\begin{abstract}
:
INTRODUCTION-Bleaching is a popular and common method used to enhance the brightness of teeth, but controversial results have been documented concerning its effects on restorative materials. Bleaching is based upon hydrogen peroxide as the active agent, which may be applied directly or released by a chemical reaction from carbamide peroxide. The purpose of this study was to evaluate the effect of home-bleaching agents $(20 \%$ $C P$ ) on the surface roughness of five restorative materials (composite resins, RMGIC, Miracle Mix, amalgam and ceramic) during 3-week experimental period.

MATERIALS AND METHOD :-20\% Carbamide peroxide (Opalescence,Ultradent), Composite resin-filtek Z350,3M ESPE,USA ,Ceramic-VITA PM9 Press Ceramic System, Germany, Resin modified Glass ionomer cement-GC Fuji II LC,GC., Amalgam-DPI Alloy, Miracle mix- GC Fuji II ,GC., Distilled Water, Finishing and polishing kit SHOFU INC Kyoto Japan.100 round disc of same dimension of various restorative materials was made. The sample was stored in a incubator to simulate the environment similar to oral cavity at $37^{\circ}$ c for 24 hours during the test. 20 sample of each group was made for each of the restorative material and further subdivided into two subgroups.
\end{abstract}

SUB GROUPING OF SAMPLE:-

a. SUBGROUP 1:- $(n=10)$ Control group-in this group sample stored in only distilled Water for 21 days.

b. SUBGROUP 2:- $(n=10)$ In this group 20\% Carbamide peroxide was applied on the samples for 6hours a day \& remaining 18 hours samples was immersed in distilled Water for 21 days.

Each sample will be analyzed at baseline and after 21 days by the profilometer. The results were analyzed statistically using analysis of variance and the Student t test

$(P<.05)$. Multiple Comparison: Tukey Test

RESULT-After using 20\% carbamide peroxide bleaching agent composite and ceramic group not showed any significant difference in surface roughness, but remaining all group including RMGIC, amalgam and miracle mix showed significant difference after bleaching.

CONCLUSION-Thorough patient examinations must be completed before, during, and after bleaching treatment. Further, replacement treatment should be carried out if it is required.

KEY WORDS- carbamide peroxide, surface roughness, composite, RMGIC, amalgam, ceramic and miracle mix

\section{INTRODUCTION}

Since the introduction of tooth whitening by Haywood and Heymann in 1989, this trend is getting more popular.[1]

Bleaching is a popular and common method used to enhance the brightness of teeth, but controversial results have been documented concerning its effects on restorative materials [2].

Bleaching is based upon hydrogen peroxide as the active agent, which may be applied directly or released by a chemical reaction from carbamide peroxide [3]. The latter acts as a deposit material releasing hydrogen peroxide and urea [4].Types of bleaching methods include nonvital bleaching, in-office professional bleaching, and home bleaching. 
Nightguard home bleaching uses a relatively low concentration of whitening agent and is applied to the teeth via a custom-fabricated mouthguard and is worn at night for a time period of at least two weeks. [5]

It was reported that the bleaching agent, regardless of the whitening products used, will reduce the microhardness of the enamel and promote an increase in surface roughness. [6]

Surface roughness of the restorations is important, as it plays a major role in the formation of biofilms and bacterial adhesion [7], that may lead to gingival inflammation [8]. Furthermore, surface restorations not only results in optimal aesthetics such as extrinsic staining [9] but also provide for acceptable health of soft tissues and marginal integrity of the restorative interface [10].

The effect of bleaching agents on the properties of the restorative materials is important. Several studies have evaluated its effect both on the mechanical and physical properties of restoratives [11].

However, investigations on surface roughness of restoratives after bleaching treatment have shown contradictory results. The opposing results may be attributed to the diverse bleaching protocols and materials tested.

The purpose of this study was to evaluate the effect of home-bleaching agents $(20 \% \mathrm{CP})$ on the surface roughness of five restorative materials (composite resins ,RMGIC, Miracle Mix, amalgam and ceramic)during 3-week experimental period.

\section{MATERIALS AND Method}

This in vitro study was carried out in the Department of Conservative Dentistry \& Endodontics, with the aim to evaluate effect of $20 \%$ carbamide peroxide on surface roughness of various restorative material.

MATERIALS :-20\% Carbamide peroxide (Opalescence,Ultradent), Composite resin-filtek Z350,3M ESPE,USA ,Ceramic-VITA PM9 Press Ceramic System, Germany, Resin modified Glass ionomer cement-GC Fuji II LC,GC., Amalgam-DPI Alloy, Miracle mix- GC Fuji II ,GC., Distilled Water, Finishing and polishing kit SHOFU INC Kyoto Japan.

A custom made metallic mould measuring $12 \mathrm{~mm}$ in diameter \& $2 \mathrm{~mm}$ height were fabricated $(12 \mathrm{~mm} \times 2 \mathrm{~mm})$. 100 sample each of amalgam, composite, RMGIC, miracle mix and ceramic were prepared using metallic mould. Amalgam specimens were burnished and polished. Composite, RMGIC, Miracle Mix and ceramic specimens were finished and polished. A pre bleaching surface roughness were measured using Profilometer (TR-110 (ADVANCE) TIME HOLLAND LTD).

The specimens were store in a humid environment oven at $37^{\circ} \mathrm{c}$ for 24 hours during the test. 20 sample were subdivided into two subgroups of each materials.

\section{SUB GROUPING OF SAMPLE:-}

a. SUBGROUP 1:- $(n=10)$ Control group-in this group sample stored in only distilled Water for 21 days.

b. SUBGROUP 2:- $(n=10)$ In this group $20 \%$ Carbamide peroxide was applied on the samples for 6hours a day \& remaining 18 hours samples was immersed in distilled Water for 21 days.

carbamide peroxide was applied to all the samples for 6 hours daily, After completion of immersion period the sample was rinsed in tap water dried with absorbent paper, and immersed in distilled water for the remaining 18 hours of the day.

The immersion treatment was performed for 21 days, during which the control sample was store in distlled water.

\section{TESTING OF SAMPLE}

Each sample was analyzed after 21 days by the surface roughness tester TR-110 (ADVANCE) TIME HOLLAND LTD.

The results were analyzed statistically using analysis of variance and the Student $t$ test $(P<.05)$. Multiple Comparison: Tukey Test.

Table-1Descriptive Statistics

\begin{tabular}{|c|c|c|c|c|c|c|c|c|}
\hline \multirow[t]{2}{*}{ Material } & \multirow[t]{2}{*}{$\mathrm{N}$} & \multirow[t]{2}{*}{ Mean } & \multirow{2}{*}{$\begin{array}{l}\text { Std. } \\
\text { Deviation }\end{array}$} & \multirow[t]{2}{*}{ Std. Error } & \multicolumn{2}{|c|}{$\begin{array}{l}95 \% \text { Confidence Interval for } \\
\text { Mean }\end{array}$} & \multirow[t]{2}{*}{ Minimum } & \multirow[t]{2}{*}{ Maximum } \\
\hline & & & & & Lower Bound & Upper Bound & & \\
\hline Amalgam & 5 & 0.27 & 0.15 & 0.07 & 0.07 & 0.46 & 0.12 & 0.50 \\
\hline Composite & 5 & 0.16 & 0.23 & 0.10 & -0.13 & 0.46 & 0.01 & 0.59 \\
\hline RMGIC & 5 & 0.28 & 0.22 & 0.10 & 0.00 & 0.56 & 0.10 & 0.67 \\
\hline Miracle Mix & 5 & 1.31 & 0.62 & 0.28 & 0.53 & 2.10 & 0.57 & 1.85 \\
\hline Ceramic & 5 & 0.07 & 0.06 & 0.02 & -0.002 & 0.15 & 0.02 & 0.15 \\
\hline
\end{tabular}


Table-2One way ANOVA

\begin{tabular}{|l|l|l|l|l|l|}
\hline Sources of variation & Sum of Squares & df & Mean Square & F & p-value \\
\hline Between Groups & 5.15 & 4 & 1.28 & & \multirow{2}{*}{12.07} \\
\hline Within Groups & 2.13 & 20 & 0.10 & & \\
\cline { 1 - 4 } Total & 7.28 & 24 & & & \\
\hline
\end{tabular}

Table-3Multiple Comparison: Tukey Test

\begin{tabular}{|c|c|c|c|c|c|c|}
\hline \multirow{2}{*}{\multicolumn{2}{|c|}{ Material }} & \multirow{2}{*}{$\begin{array}{l}\text { Mean Difference } \\
\text { (I-J) }\end{array}$} & \multirow{2}{*}{ Std. Error } & \multirow{2}{*}{$p$-value } & \multirow{2}{*}{$\begin{array}{l}95 \% \\
\text { Interval } \\
\text { Lower } \\
\text { Bound }\end{array}$} & Confidence \\
\hline & & & & & & $\begin{array}{l}\text { Upper } \\
\text { Bound }\end{array}$ \\
\hline \multirow{4}{*}{ Amalgam } & Composite & 0.11 & 0.20 & $0.983, \mathrm{NS}, \mathrm{p}>0.05$ & -0.50 & 0.72 \\
\hline & RMGIC & -0.01 & 0.20 & $1.000, \mathrm{NS}, \mathrm{p}>0.05$ & -0.62 & 0.60 \\
\hline & Miracle Mix & -1.04 & 0.20 & $0.001, \mathrm{~S}, \mathrm{p}<0.05$ & -1.66 & -0.42 \\
\hline & Ceramic & 0.19 & 0.20 & $0.870, \mathrm{NS}, \mathrm{p}>0.05$ & -0.42 & 0.81 \\
\hline \multirow{3}{*}{ Composite } & RMGIC & -0.12 & 0.20 & $0.976, \mathrm{NS}, \mathrm{p}>0.05$ & -0.73 & 0.49 \\
\hline & Miracle Mix & -1.15 & 0.20 & $0.000, \mathrm{~S}, \mathrm{p}<0.05$ & -1.77 & -0.53 \\
\hline & Ceramic & 0.08 & 0.20 & $0.993, \mathrm{NS}, \mathrm{p}>0.05$ & -0.53 & 0.70 \\
\hline \multirow{2}{*}{ RMGIC } & Miracle Mix & -1.03 & 0.20 & $0.001, \mathrm{~S}, \mathrm{p}<0.05$ & -1.65 & -0.41 \\
\hline & Ceramic & 0.20 & 0.20 & $0.849, \mathrm{NS}, \mathrm{p}>0.05$ & -0.41 & 0.82 \\
\hline Miracle Mix & Ceramic & 1.24 & 0.20 & $0.000, \mathrm{~S}, \mathrm{p}<0.05$ & 0.62 & 1.86 \\
\hline
\end{tabular}

Graph 1: Comparison of Surface Roughness (Ra) in five materials for $20 \% \mathrm{CP}$

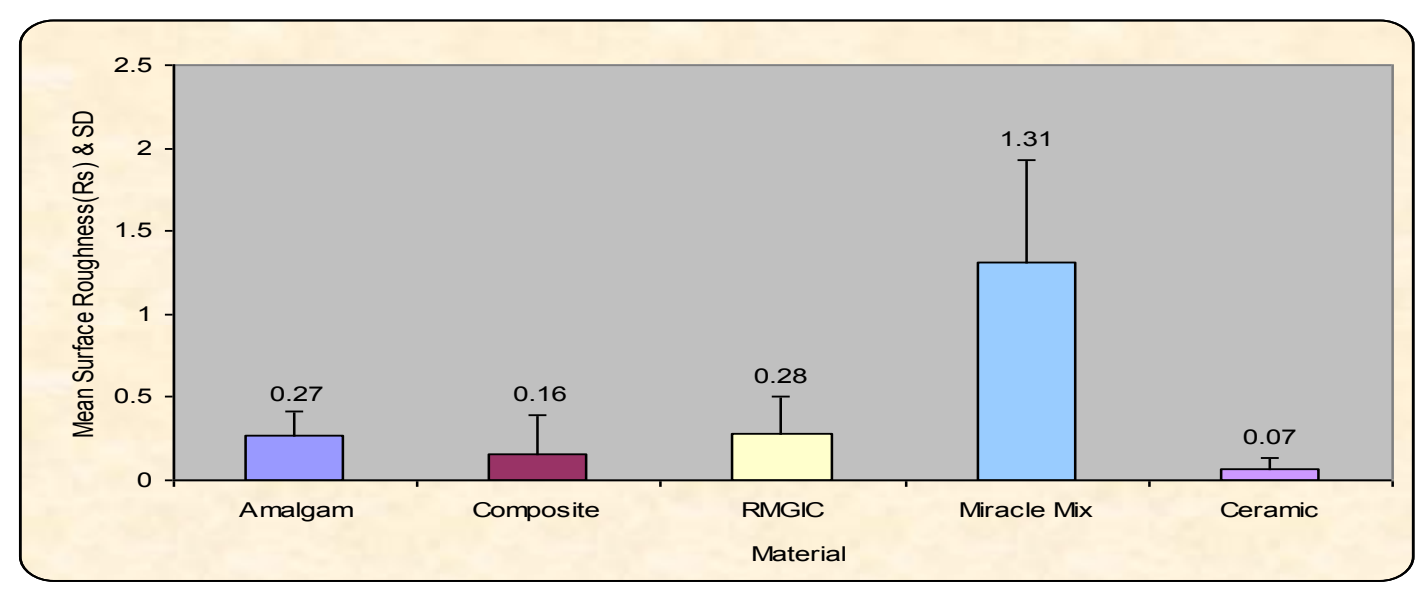

III. OBSERVATION AND RESULT

According to table1,2 and 3 and graph 1 showing composite filtek Z-350 and ceramic was smoother among all the tested group of bleaching followed by Resin Modified GIC, amalgam and Miracle mix.

After using $20 \%$ carbamide peroxide bleaching agent composite and ceramic group not showing any significant difference in surface roughness, but remaining all group including RMGIC, amalgam, and miracle mix showed significant difference after bleaching.

Miracle mix showed highest surface roughness amongst all the five restorative materials after bleaching treatment.

\section{Discussion}

Interaction between whitening agents and oral structures is of critical importance, and some chemical aspects involved in bleaching could negatively interfere with this. The oxidative process, with its low resulting $\mathrm{pH}$, has been considered as a potential source of adverse effects $[12,26]$.

Surface roughness is a clinically important property that warrants investigation, since it can influence both aesthetics and health. 
A plethora of home bleaching products, most containing $20 \%$ carbamide peroxide, are currently available.[27-30].

Thereby, in the present study, the effects of $20 \%$ bleaching agent on surface roughness of key restorative materials (composite, Resin Modifide GIC, ceramic, amalgam and Miracle mix.) were evaluated.

The results obtained from this in vitro study demand rejection of the first null hypothesis that there were no significant differences in surface roughness among the restorative materials tested after bleaching.

This is in agreement with previous studies, which investigated the effect of home-bleaching agents on surface roughness of various restorative materials [31-35].

Composite filtek Z-350 and ceramic is smoother among all the tested group of bleaching followed by Resin Modifide GIC, amalgam and Miracle mix.

After using 20\% carbamide peroxide bleaching agent composite and ceramic group not showing any significant difference, but remaining all group including RMGIC, amalgam and miracle mix showing significant difference after bleaching.

In the current study, surface roughness of universal nanocomposite (Filtek Z350), did not affect significantly by $20 \%$ carbamide peroxide.

The increased surface roughness may be attributed to erosion of resin matrix from free radicals of peroxide which leads to debonding of resin-filler interfaces and to dislodgment and elution of fillers. Consequently, the higher the volume and the size of leached particles of the materials, the rougher the resulting surface.[36].

On the other hand, little is known about the influence of bleaching on ceramics [37].

Zavanelli et al.,[38] found no alterations on ceramic surfaces treated with $10 \%$ or $15 \%$ carbamide peroxide for $126 \mathrm{~h}$.

Butler et al. [39] reported that porcelains might have significant roughening from $10 \% \mathrm{CP}$ treatment.

No Significant alteration in ceramic surfaces was observed after bleaching in the current study.

The changes in physical, mechanical and corrosion characteristics are related to the nature of the amalgam matrix and the corrosive environment of the mouth. The mercury matrix phase is a major phase in any set amalgam and an important source for continuous and sometimes prolonged mercury release, which may be increased by exposure to heat, acids, or other agents [40,41,42].

In this study, carbamide peroxide may have facilitated the degradation of the amalgam surface. Acidic environment significantly affects corrosive behaveior of the alloys and particularly the amalgam, so mercury release can be related to this acidic $\mathrm{pH}$ rather than the effect of the peroxide by- products itself.

An increase in roughness has been observed in composite resins or glass ionomers after bleaching treatment, $[38,43]$

Particle size has been shown to play an important role in how well a material polishes. Some size. $[44,45]$

studies have been recorded the highest values of surface roughness for the materials with larger particle

The average particle size of miracle mix (metal modified GIC) is greater than resin modified GIC.[46].

Also, the storage media of GIC specimens can affect their surface roughness. In the present study, the prepared GIC specimens were stored in distilled water at $37{ }^{\circ} \mathrm{C}$ for $24 \mathrm{~h}$ to mimic clinic conditions. The chemical dissolution process can produce an increase in surface roughness [47].

However; one study evaluated the effects of storage media upon the surface micromorphology of resinbased materials and revealed no statistically significant difference in surface roughness between specimens exposed to distilled deionized water or artificial saliva.[48].

In the current study out of all the five restorative materials miracle mix showed the highest surface roughness after bleaching agent application.

However the literature regarding the surface roughness of miracle mix after bleaching application is very rare, so further research in this field should be carried out .

\section{Conclusion}

Thorough patient examinations must be completed before, during, and after bleaching treatment. Further, replacement treatment should be carried out if it is required.

\section{LIMITATION OF THE STUDY}

- Study performed in in-vitro condition which may not simulate oral environment for restorative material.

- Limited restorative material required were compare with limited concentration of bleaching agent.

- Long term clinical trial must be done in future. 


\section{References}

[1]. Haywood VB, Heymann HO. Nightguard vital bleaching. Quintessence Int 1989;20:173-6.

[2]. Attin T, Hannig C, Wiegand A, Attin R. Effect of bleaching on restorative materials and restorations - a systematic review. Dent Mater 2004; 20: 852-861.

[3]. Dahl J, Pallesen U. Tooth bleaching — a critical review of the biological aspects. Crit Rev Oral Biol Med 2003; $14: 292-304$.

[4]. Schmalz G, Arenholt-Bindslev D. Biocompatibility of dental materials. Berlin: Springer; 2009. p. 284.

[5]. Greenwall L. Bleaching techniques in restorative dentistry-an illustrated guide. London: Martin Dunitz Ltd; 2001.

[6]. Pinto CF, Oliveira R, Cavalli V, Giannini M. Peroxide bleaching agent effects on enamel surface microhardness, roughness and morphology. Braz Oral Res 2004;18:306-11.

[7]. Hosoya N, Honda K, Iino F, Arai T. Changes in enamel surface roughness and adhesion of Streptococcus mutans to enamel after vital bleaching. J Dent 2003; 31: 543-8.

[8]. Bollen CM, Lambrechts P, Quirynen M. Comparison of surface roughness of oral hard materials to the threshold surface roughnes s for bacterial plaque retention: A review of the literature. Dent Mater 1997; 13: 258-69.

[9]. Cavalli V, Arrais CA, Giannini M, Ambrosano GM. High-concentrated carbamide peroxide bleaching agents effects on enamel surface. J Oral Rehabil. 2004; 31: 155-9.

[10]. Heath JR, Wilson HJ. Surface roughness of restorations. Br Dent J. 1976; 140: 131-7.

[11]. Attin T, Hannig C, Weigand A, Attin R. Effect of bleaching on restorative materials and restorations - a systematic review. Dent Mater. 2004; 20: 852-61.

[12]. Basting RT, Rodrigues AL Jr, Serra MC (2003) The effects of seven carbamide peroxide bleaching agents on enamel microhardness over time. J Am Dent Assoc 134:1335-1342

[13]. Bitter NC (1998) A scanning electron microscope study of the long-term effect of bleaching agents on the enamel surface in vivo. Gen Dent 46:84-88

[14]. Bollen CM, Lambrechts P, Quirynen M (1997) Comparison of surface roughness of oral hard materials to the threshold surface roughness for bacterial plaque retention: a review of the literature. Dent Mater 13:258-269

[15]. Butler CJ, Masri R, Driscoll CF, Thompson GA, Runyan DA, von Fraunhofer JA (2004) Effect of fluoride and 10\% carbamide peroxide on the surface roughness of low-fusing and ultra low-fusing porcelain. J Prosthet Dent 92:179-183

[16]. Canay Ş, Çehreli MC (2003) The effect of current bleaching agents on the color of light-polymerized composites in vitro. J Prosthet Dent 89:474-478

[17]. Cavalli V, Arrais CA, Giannini M, Ambrosano GM (2004) High-concentrated carbamide peroxide bleaching agents effects on enamel surface. J Oral Rehabil 31:155-159

[18]. Çobankara FK, Ünlü N, Altinöz HC, Özer F (2004) Effect of home bleaching agents on the roughness and surface morphology of human enamel and dentine. Int Dent J 54:211-218

[19]. Dahl JE, Pallesen U (2003) Tooth bleaching — a critical review of the biological aspects. Crit Rev Oral Biol Med 14:292-304

[20]. Ernst CP, Marroquin BB, Willershausen-Zönnchen B (1996) Effects of hydrogen peroxide-containing bleaching agents on the morphology of human enamel. Quintessence Int 27:53-56

[21]. García-Godoy F, García-Godoy A, García-Godoy F (2002) Effect of bleaching gels on the surface roughness, hardness and micromorphology of composites. Gen Dent 50:247-250

[22]. Haywood VB (1992) History, safety, and effectiveness of current bleaching techniques and applications of the nightguard vital bleaching technique. Quintessence Int 23:471-488

[23]. Hosoya N, Honda K, Iino F, Arai T (2003) Changes in enamel surface roughness and adhesion of Streptococcus mutans to enamel after vital bleaching. J Dent 31:543-548

[24]. Kim JH, Lee YK, Lim BS, Rhee SH, Yang HC (2004) Effect of tooth-whitening strips and films on changes in color and surface roughness of resin composites. Clin Oral Invest 8:118-122

[25]. Langsten RE, Dunn WJ, Hartup GR, Murchison DF (2002) Higher-concentration carbamide peroxide effects on surface roughness of composites. J Esthet Restor Dent 14:92-96

[26]. Lewinstein I, Fuhrer N, Churaru N, Cardash H (2004) Effect of different peroxide bleaching regimens and subsequent fluoridation on the hardness of human enamel and dentin. J Prosthet Dent 92:337-342

[27]. Ctiristensen GJ: Tooth bieaching, home-use products. Clin ResAssoe Newsielter 1989;13(7):1-3.

[28]. Christensen GJ: Tootti bleactiing, home-use products (update report). Clm Res Assoc Newsletter 1989;13(12):1.-3.

[29]. Haywood VB: Nightguard vital bleaching: current information and research. Eslhet Dem Update 1990;1:20-25.

[30]. Albers HF(ed): Lightening teeth.ADEPT Report 1990;2:1-24.

[31]. Moraes RR, Marimon JLM, Schneider LFJ, Correr Sobrinho L, Camacho GB, Bueno M. Carbamide peroxide bleaching agents: effects on surface roughness of enamel, composite and porcelain. Clin Oral Invest. 2006; 10: 23-8.

[32]. Turker SB, Biskin T. Effect of three bleaching agents on the surface properties of three different esthetic restorative materials. J Prosthet Dent. 2003; 89: 466-73.

[33]. Cehreli ZC, Yazici R, Garcia-Godoy F. Effect of home-use bleaching gels on fluoride releasing restorative materials. Oper Dent. 2003; 28: 605- 9 .

[34]. Zavanelli AC, Mazaro VQ, Silva CR, Zavanelli RA, Mancuso DN. Surface roughness analysis of four restorative materials exposed to $10 \%$ and $15 \%$ carbamide peroxide. Int J Prosthodont. 2011; 24: 155-7.

[35]. Wattanapayungkul P, Yap AUJ, Chooi KW, Lee MFLA, Selamat RS, Zhou RD. The effect of home bleaching agents on the surface roughness of tooth-colored restoratives with time. Oper Dent 2004; 29: 398-403.

[36]. Dionysopoulos D, Koliniotou-Koumpia E, Gerasimou P, Papadopoulos C (2013) The Effect of Home-Bleaching Agents on Surface Roughness of Restorative Materials. JSM Dent 1(3): 1015.

[37]. Attin T, Hannig C, Wiegand A, Attin R (2004) Effect of bleaching on restorative materials and restorations-a systematic review. Dent Mater 20:852-861.

[38]. Zavanelli AC, Mazaro VQ, Silva CR, Zavanelli RA, Mancuso DN. Surface roughness analysis of four restorative materials exposed to $10 \%$ and $15 \%$ carbamide peroxide. Int J Prosthodont. 2011 May-Apr;24(2):155-7.

[39]. Butler CJ, Masri R, Driscoll CF, Thompson GA, Runyan DA, von Fraunhofer JA (2004) Effect of fluoride and 10\% carbamide peroxide on the surface roughness of low-fusing and ultra low-fusing porcelain. J Prosthet Dent 92:179-183.

[40] Little JW, Falace DA, Miller CS. Dental management of the medically compromised patient. $6^{\text {th }}$ ed. St Louis: Mosby; 2002. p. 329330 .

[41] Rotstein I, Dogan H, Avron Y, Shemesh H, Mor C, Steinberg D. Protective effect of Copalite surface coating on mercury release from dental amalgam following treatment with carbamide peroxide. Endod Dent Traumatol 2000; 16: 107-110. 
[42] Soh G, Chew CL, Lee AS, Yeoh TS. Significance of hydrogen ion concentration on the dissolution of mercury from dental amalgam. Quintessence Int 1991; 22: 225-228.

[43]. Turker SB, Biskin T. Effect of three bleaching agents on the surface properties of three different esthetic restorative materials. J Prosthet Dent. 2003 May;89(5):466-73.

[44]. Gladys S, Van Meerbeek B, Braem M, Lambrechts P, Vanherle G. Comparative pysico-mechanical characterization of new hybrid restorative materials with conventional glass-ionomer and resin composite restorative materials. J Dent Res 1997;76:883-894.

[45]. Reis AF, Giannini M, Lovadino JR, Ambrosano GM. Effects of various finishing systems on the surface roughness and staining susceptibility of packable composite resins. Dent Mater 2003;19:12-18.

[46]. Oya Bala, Hacer Deniz Arisu, Ihsan Yikilgan,Seda Arslan,Abdulkadir Gullu, Evaluation of surface roughness and hardness of different glass ionomer cements, European Journal of Dentistry,January 2012 - Vol.6

[47]. Roulet JF, Walti C. Influence of oral fluid on composite resin and glass-ionomer cement. J Prosthet Dent 1984;52:182- 189.

[48]. Turssi CP, Hara AT, Serra MC, Rodrigues AL. Effect of storage media upon the surface micromorphology of resinbased restorative materials. J Oral Rehabil 2002;29:864- 871. 